\title{
Larval nematodes in stomach wall granulomas of smelt Osmerus eperlanus from the German North Sea coast
}

\author{
A. I. Obiekezie ${ }^{1}$, R. Lick ${ }^{2}$, S. Kerstan ${ }^{2}$, H. Möller ${ }^{2, *}$ \\ ${ }^{1}$ Institute of Oceanography, University of Calabar, PMB 115, Calabar, Nigeria \\ ${ }^{2}$ Institut für Meereskunde, Universität Kiel, Düsternbrooker Weg 20, W-2300 Kiel 1, Germany
}

\begin{abstract}
Occurrence of stomach wall granulomas in European smelt was studied at 6 locations along the German North Sea coast. Identification of larval nematodes inhabiting these granulomas is provided for the first time. Three species, isolated by pepsin- $\mathrm{HCl}$ digestion, are involved: Hysterothylacium cf. cornutum, Cosmocephalus obvelatus and Paracuaria tridentata. $72 \%$ of all stomachs examined were affected. The ratio of number of granulomas to number of the 3 larval species free in the mesentery was 1:1.3. Differences in prevalences and intensities were significant among all locations. Granuloma abundance was highest in samples from the Elbe estuary decreasing in the other locations relative to their distance from the Elbe. There was no relationship between the number of larvae encapsulated on the stomach wall and the number of larval $P$. decipiens in the musculature $(\mathrm{r}=0.3)$. Host condition factor could not be related to number of granulomas. Smelt appears to be an important transmitter of spiruroid nematode larvae to marine birds in this region.
\end{abstract}

\section{INTRODUCTION}

The European smelt Osmerus eperlanus L. is widely distributed in the estuaries of the larger rivers in northern Europe and in neighbouring coastal areas. Data on the general biology of the species in these locations are available in Lillelund (1961) and Möller (1984). The parasitology of the European smelt has been fairly extensively investigated both in the North Sea (Kahl 1936, Jarling 1982, Möller 1984, Möller \& Klatt 1990, Kerstan 1991, Lick 1991) and in the Baltic (Voigt 1975, 1981, 1989).

Most published studies on smelt parasites, however, have concentrated on Pseudoterranova decipiens as part of the efforts to understand the biology of this conspicuous species which occurs as adults in seals. While much has been done to identify and quantify the species of nematode larvae either in the musculature or body cavity of smelt, no similar information exists on those larvae encapsulated within stomach wall granu-

\footnotetext{
- Addressee for correspondence
}

lomas, in spite of their value for assessing variations in nematode infestations since they represent the most recent acquisitions (Grabda 1978).

Möller \& Anders (1986) first documented the occurrence of numerous whitish granulomas on the stomach wall of smelt, although the nature of their contents was not determined. Previously, Jarling (1982) referred briefly to Thynnascaris sp. and 'spiruroid' larvae in the intestinal wall of the same host from the Elbe River. Apparently, the full complement of the nematode species of Osmerus eperlanus from the North Sea has not been fully investigated nor is there any information on the contents of the stomach granulomas, or on their significance and regional distribution.

The present study was undertaken as part of a wider investigation into the biology and disease occurrence of fishes from the Wadden Sea. The aim was to obtain data on the identity of nematode larvae inhabiting stomach wall granulomas of smelt, and their host relations and occurrence pattern in the locality. Such data would provide additional information on regional differences in parasite occurrence of the species and might prove of value as biological indicators of local smelt populations. 


\section{MATERIALS AND METHODS}

Between July and September 1988, 576 specimens of European smelt ranging in total length from 15 to $20 \mathrm{~cm}$ were collected from several locations on the lower reaches of 4 rivers which empty into the North Sea (Ems, Weser, Elbe, Eider) and from Suderaue and Heverstrom on the northern part of the German Wadden Sea (Fig. 1). The fish samples originated from trawl

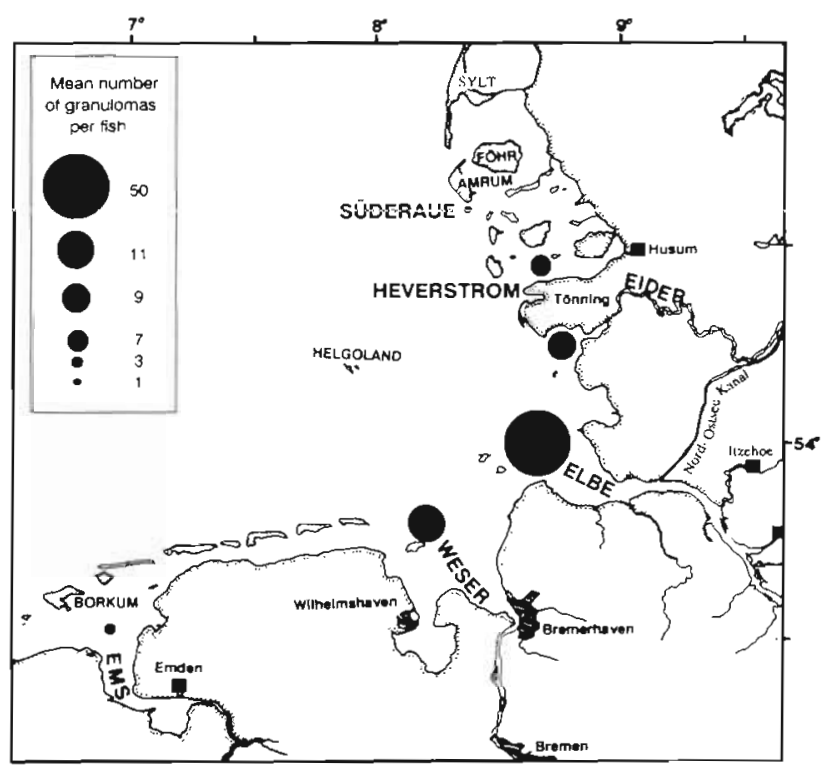

Fig. 1. Osmerus eperlanus. German North Sea coast showing locations and geographical variations in abundance of stomach wall granulomas in European smelt $(15$ to $20 \mathrm{~cm}$ ). Symbols show mean number of granulomas per fish (including non-infected individuals)

catches. For each fish sample, data on standard length as well as total and gutted weight were recorded. Condition factor was calculated as $K=$ (gutted weight in $\mathrm{g}) \times 1000 /($ length in $\mathrm{cm}$ ). Age was determined by otolith reading.

Stomachs dissected from each fish were cut open, cleaned and the wall examined under stereomicroscopy $(50 \times)$ for the presence of granulomas. Relationships between granuloma counts and number of nematode species in the musculature were determined by simultaneous filleting and examination over a candling table.

Larvae were recovered from the granulomas, sometimes still alive, through pepsin-HCL digestion during incubation at $35^{\circ} \mathrm{C}$ (Smith \& Wootten 1975), washed and subsequently transferred to a mixture of ethanol and glycerine. For each location subsamples of infected specimens were pooled together and digested to determine the proportions of each granuloma-inhabiting larval species.

Due to the wide differences in intensities, the counts were transformed to stabilize the variance using the equation suggested by Bishop \& Margolis (1955)

$$
y=\log 10(x+1)
$$

where $y=$ transformed value of original observation $x$. Subsequent statistical analyses were performed on the transformed values. Quantitative terms used in the paper conform to the definitions of Margolis et al. (1982).

\section{RESULTS}

Three nematode larval species, Cosmocephalus obvelatus, Paracuaria tridentata and Hysterothylacium sp. cf. cornutum, were recovered by pepsin- $\mathrm{HCl}$ digestion from stomach wall granulomas (Figs. 2 \& 3). On 1 additional occasion, a single Spinitectus sp. larva was found encapsulated on the stomach. Larvae of $C$. obvelatus and $P$. tridentata corresponded in morphology and size to parasites described by Plotz $(1982 a, b)$ from fishes and birds near Helgoland, Germany.

The following description of Hysterothylacium larvae is based on examination of 20 specimens from both stomach ganulomas and mesentery. Measurements are in micrometers unless otherwise stated:

Body 1.75 to $1.85 \mathrm{~mm}$ long by 70 to 80 wide at greatest width; ratio of greatest width to length $1: 10$ to 15 . Cuticle lacks lateral alae. Oesophagus 165 to 170 long, 2 to 2.5 wide, constituting 8 to $10 \%$ of body length.

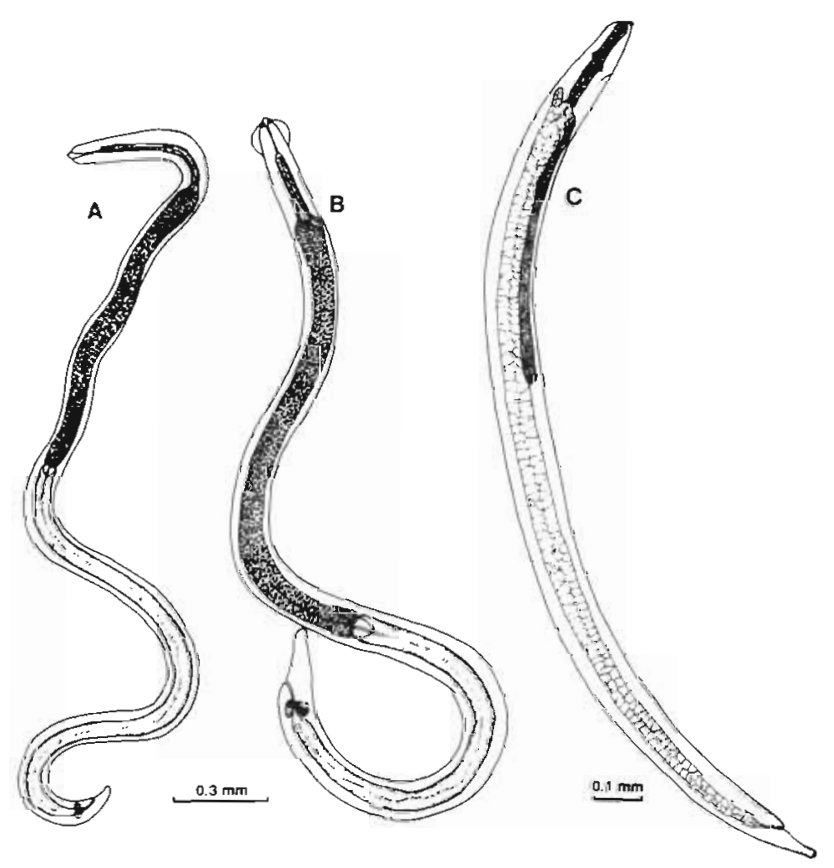

Fig. 2. Nematode larvae from stomach wall granulomas of Osmerus eperlanus. (A) Paracuana tridentata. (B) Cosmocephalus obvelatus. (C) Hysterothylacium cf. cornutum 


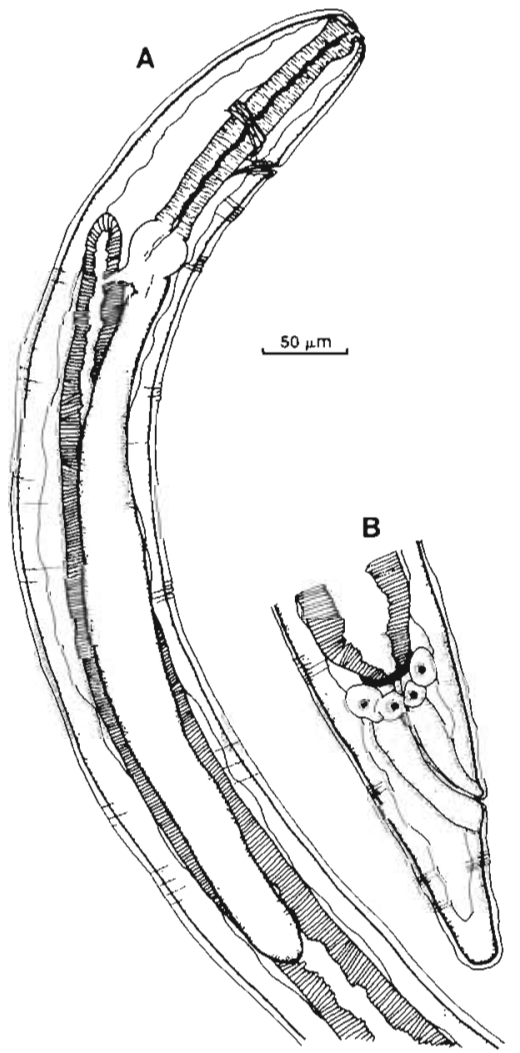

Fig. 3. Hysterothylacium cf. cornutum. Details of (A) head region and $(B)$ tail

Ventriculus 25 to 30 in diameter; ventricular appendage 510 to 530 long by 2 to 3 wide. Ratio of ventricular appendage length to body length $1: 3.5$ to 4.0 ; and to the oesophagus length 1:0.30 to 0.35. Intestinal caecum 20 to 25 long by 10 to 15 wide; ratio of caecal to ventricular appendage lengths $1: 18$ to 22 ; ratio of caecal to oesophagus lengths $1: 7$ to 10 . Distance of nerve ring from anterior end 120 to 125 (or within anterior 60 to $70 \%$ of the oesophagus), breadth 10 to 12 . Excretory pore opens at about the nerve ring level or slightly posterior thereto. Tail bluntly rounded without spines, 65 to 72 long or 3 to $4 \%$ of the body length.

The relationship between lengths of intestinal and ventricular caeca are close to those of Hysterothylacium cornutum as described by Petter (1969). Berland (1961) found adults of the species in Thunnus thynnus from Norwegian waters.

Granulomas on the stomach wall were detected in smelt from all locations sampled. Prevalence and intensity varied greatly among the localities (Table 1). The highest occurrence of infection was found in fish sampled from the Elbe and the lowest in Süderaue. A paired comparison $t$-test showed significant differences ( $\mathrm{p}<0.001$ ) in granuloma counts between the various locations. A negative correlation $(r=0.76)$ could be established between the mean number of granulomas in the stomach wall in the different localities and their distance from the Elbe estuary (Fig. 4). In all locations, the coefficient of dispersion indicates a highly aggregated distribution. Frequency distributions of granuloma counts according to localities based on original untransformed data are shown in Fig. 5.

When granuloma counts on stomach walls were analysed according to host sex, no significant difference could be established. This justified the combination of data from male and female fish for the purposes of subsequent analyses. Within the 15 to $20 \mathrm{~cm}$ (total length) class of fish examined, analysis of variance

Table 1. Osmerus eperlanus. Occurrence of nematode larvae in stomach wall of European smelt at several locations along the German North Sea coast

\begin{tabular}{|c|c|c|c|c|c|c|c|c|c|c|}
\hline \multirow[t]{2}{*}{ Location } & \multicolumn{5}{|c|}{ Stomach wall } & \multicolumn{5}{|c|}{ Mesenteries } \\
\hline & $\begin{array}{c}\text { No. } \\
\text { examined }\end{array}$ & $\begin{array}{c}\text { No. } \\
\text { infected } \\
\text { (Preva- } \\
\text { lence \%) }\end{array}$ & $\begin{array}{c}\text { Mean } \\
\text { intensity } \\
(\mathrm{SD})\end{array}$ & $\begin{array}{l}\text { Coefficient } \\
\text { of } \\
\text { dispersion }\end{array}$ & Range & $\begin{array}{c}\text { No. } \\
\text { examined }\end{array}$ & $\begin{array}{c}\text { No. } \\
\text { infected } \\
\text { (Preva- } \\
\text { lence \%) }\end{array}$ & $\begin{array}{c}\text { Mean } \\
\text { intensity } \\
\text { (SD) }\end{array}$ & $\begin{array}{l}\text { Coefficient } \\
\text { of } \\
\text { dispersion }\end{array}$ & Range \\
\hline Ems & 65 & $\begin{array}{l}43 \\
(66.2)\end{array}$ & $\begin{array}{c}4.7 \\
(9.9)\end{array}$ & 20.5 & $1-54$ & 65 & $\begin{array}{c}51 \\
(78.5)\end{array}$ & $\begin{array}{c}6.3 \\
(11.8)\end{array}$ & 22.2 & $1-68$ \\
\hline Weser & 65 & $\begin{array}{c}46 \\
(70.8)\end{array}$ & $\begin{array}{c}14.7 \\
(50.4)\end{array}$ & 173.1 & $1-344$ & 65 & $\begin{array}{l}60 \\
(92.3)\end{array}$ & $\begin{array}{c}19.9 \\
(63.6)\end{array}$ & 202.9 & $1-494$ \\
\hline Elbe & 83 & $\begin{array}{c}82 \\
(98.8)\end{array}$ & $\begin{array}{c}48.9 \\
(70.3)\end{array}$ & 101.2 & $1-450$ & 65 & $\begin{array}{c}64 \\
(98.5)\end{array}$ & $\begin{array}{c}77.7 \\
(117.2)\end{array}$ & 176.8 & $1-750$ \\
\hline Eider & 231 & $\begin{array}{l}196 \\
(84.8)\end{array}$ & $\begin{array}{c}9.9 \\
(15.7)\end{array}$ & 24.8 & $1-116$ & 231 & $\begin{array}{l}178 \\
(77.1)\end{array}$ & $\begin{array}{c}9.2 \\
(10.1)\end{array}$ & 11.0 & $1-100$ \\
\hline Heverstrom & 90 & $\begin{array}{l}57 \\
(63.3)\end{array}$ & $\begin{array}{c}10.3 \\
(22.6)\end{array}$ & 49.4 & $1-140$ & 90 & $\begin{array}{c}67 \\
(74.4)\end{array}$ & $\begin{array}{c}7.4 \\
(7.5)\end{array}$ & 7.6 & $1-40$ \\
\hline Süderaue & 42 & $\begin{array}{c}15 \\
(35.7)\end{array}$ & $\begin{array}{c}3.5 \\
(4.1)\end{array}$ & 4.8 & $1-16$ & 42 & $\begin{array}{c}19 \\
(45.2)\end{array}$ & $\begin{array}{c}3.5 \\
(3.7)\end{array}$ & 3.8 & $1-16$ \\
\hline
\end{tabular}




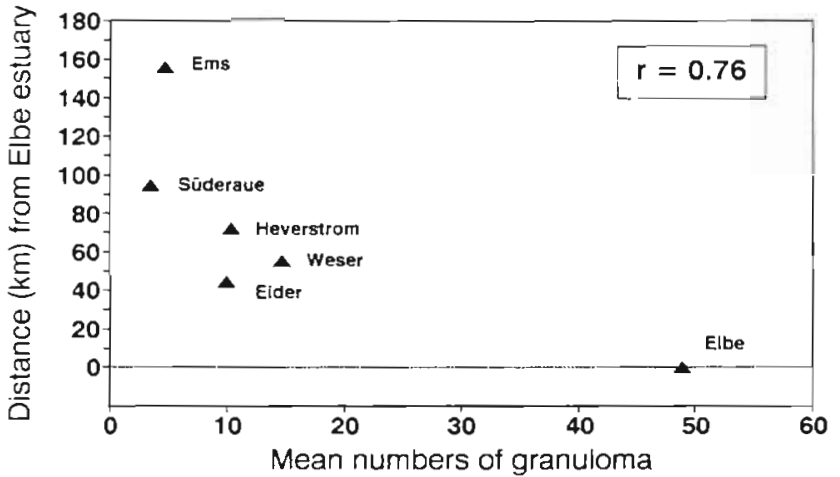

Fig. 4. Osmerus aperlanus. Relation between mean number of granuloma in smelt for 6 geographical locations and their distances from the Elbe estuary

showed no significant differences in infestation with either the length or age of host.

The numbers of granulomas on the stomach wall and of inhabitant larvae of the 3 species free in the mesentery were highly correlated $(r=0.93)$. The ratio of stomach granulomas to larvae free in the mesentery was 1:1.3 (Fig. 6). There seems to be no relation ( $\mathrm{r}=$ $0.3)$ between the number of larval Pseudoterranova decipiens in the musculature and granulomas in the stomach wall (Fig. 7).

Histologically, granulomas could be located in both the mucosa and the muscularis of the stomach wall. Encapsulated nematode larvae are surrounded by granulomatous and fibrotic tissue and varying degrees of cellular infiltration which involve a considerable portion of stomach musculature (Fig. 8). Although the condition factors of smelt differed in the various locations, these differences urere not significant and no correlation could be established between granuloma load and condition factor of hosts ( $r=0.3)$.

Distribution of granulomas on different parts of the stomach wall showed a concentration $(76.1 \%)$ on the
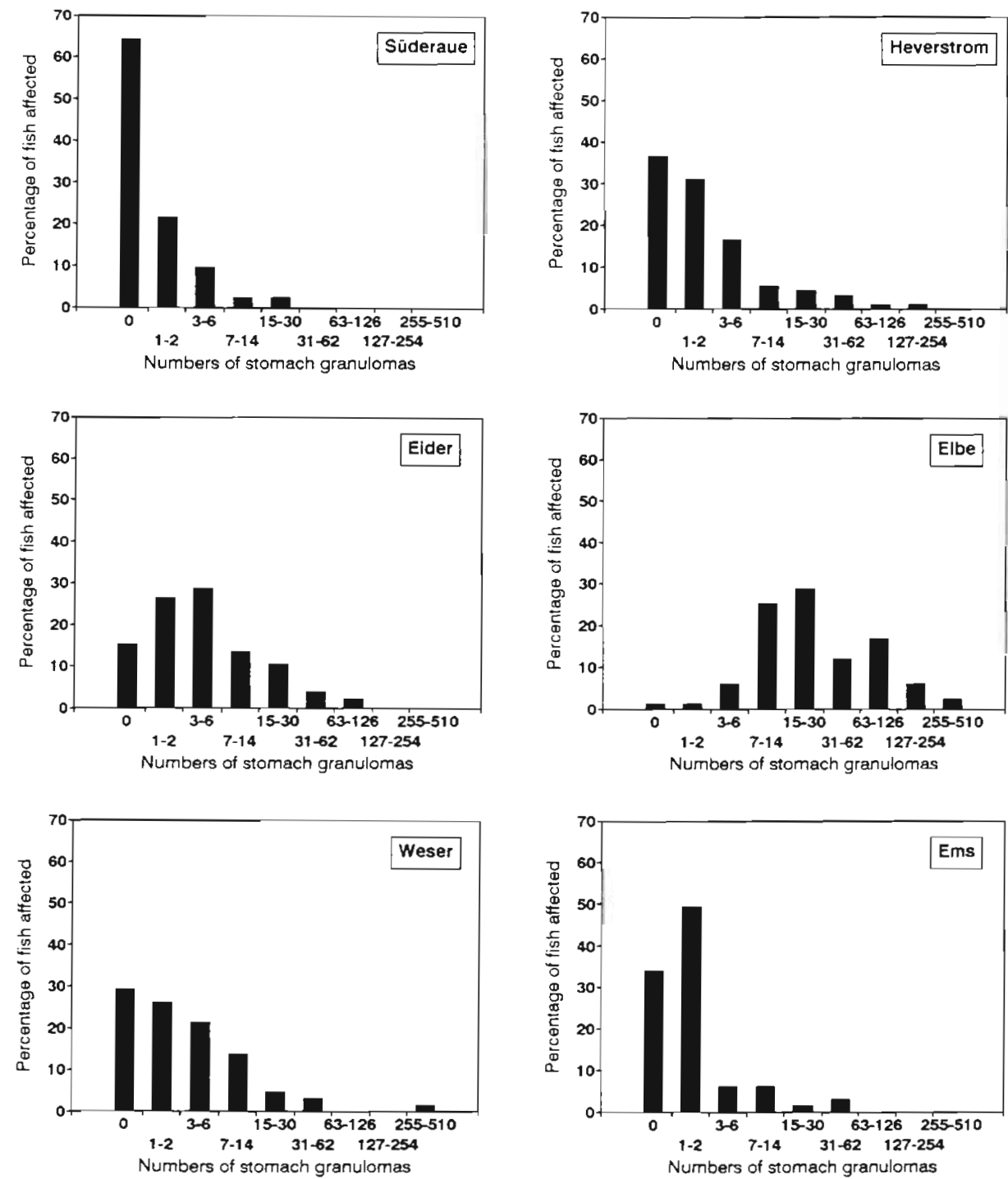
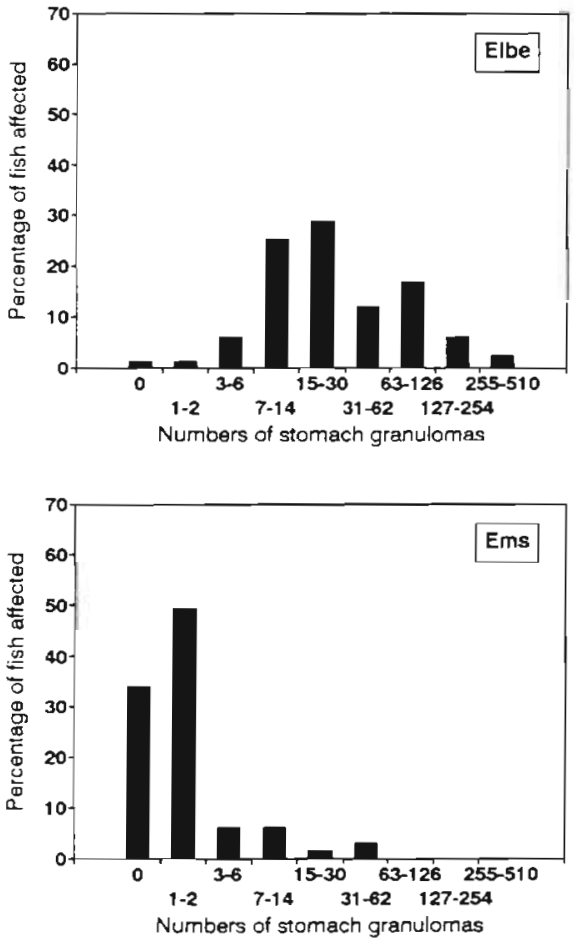

Fig. 5. Osmerus eperlanus. Relative frequency distribution of stomach wall granulomas of smelt from various locations along the German North Sea coast 


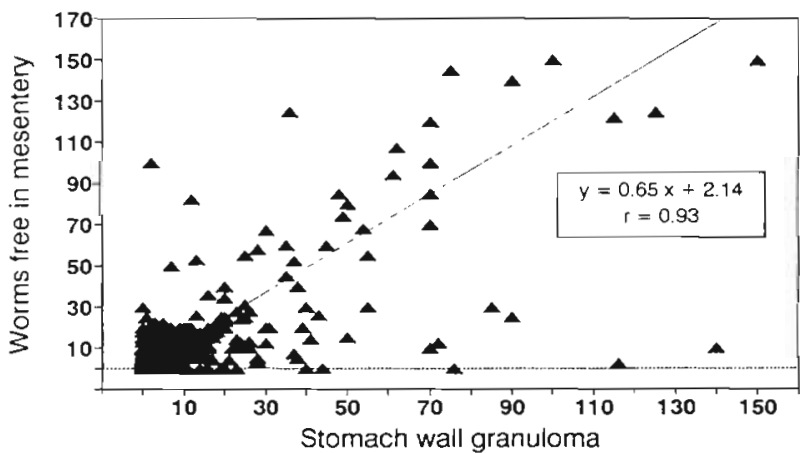

Fig. 6. Relationship between number of larval Hysterothylacium cornutum, Cosmocephalus obvelatus, Paracuaria tridentata free in the mesenteries and number of stomach wall granulomas in 576 smelt Osmerus eperlanus

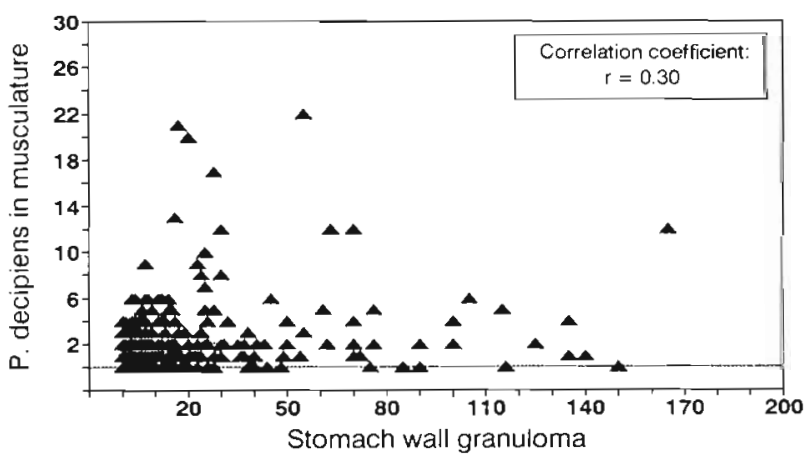

Fig. 7. Pseudoterranova decipiens, Osmerus eperlanus. Relationship between numbers of $P$. decipiens in the musculature and number of stomach wall granulomas in 576 smelt

pyloric end of this organ. The midsection of the stomach wall was affected by $23.1 \%$ of the granulomas whereas only $0.8 \%$ were located at the oesophageal end.

\section{DISCUSSION}

The present study has established that the European smelt can be infected in high numbers by 3 additional species of larval nematodes in both stomach wall granulomas and mesentery. There has been no report of these larvae in smelt from the Baltic despite extensive investigations into the parasitology of the host in this region (Voigt 1989). It is possible that they do not occur in smelt in this locality or that they have been missed in studies which did not include examination of the stomach wall.

Plötz $(1982 \mathrm{a}, \mathrm{b})$ studied the biology of the spiruroid nematodes Cosmocephalus obvelatus and Paracuaria tridentata of Laridae in the North Sea and was able to experimentally infect several species of fish in which the larvae attained the L3 stage. Field observations, however, did not lead to any indication of the fish species responsible for the transmission to Laridae in nature. It could be concluded from the present study that smelt is an important transmitter of spiruroid nematodes to marine bird species in the area of the Wadden Sea considering their high occurrence both in the mesentery and on stomach granulomas. In a parallel study, Lick (1991) isolated larvae of the 3 species from stomach granulomas in 10 out of 41 fish species examined in the Elbe estuary and confirmed Osmerus eperlanus and Acerina cernua as the most important intermediate hosts in the locality. Much lower infection rates with the L3 larvae of $C$. obvelatus have been recorded for the closely related rainbow smelt $O$. mordax in Lake Ontario (Wong \& Anderson 1982).

Differences in infection rates of first invertebrate intermediate hosts might explain the strong regional variations in granuloma and nematode occurrence in smelt. The inverse relationship of mean granuloma counts with distance from the Elbe would imply that this location serves as a focus for the dissemination of the 3 larval nematode species involved in this study.

The absence of other larval species in granulomas might imply a more rapid migration through the stomach wall. The number of granulomas evidently does not influence the passage of Pseudoterranova decipiens into the musculature.

Similar quantitative studies of granuloma occurrence on stomach wall of smelt from other areas of its occurrence are not available for comparison. The condition satisfies most criteria for use as biological tags of local smelt populations: prevalences could be high and differ significantly with localities; the condition is easily recognizable on a specific site on the host; the health of the host is apparently not impaired; and the granulomas persist for some time even after destruction of the larvae.

Acknowledgements. Figures 8A, B were taken from Anders (1988) with kind permission of the author

\section{LITERATURE CITED}

Anders, K. (1988). Biologie von Tumor- und tumorähnlichen Krankheiten der Elbfische. Verlag Heino Möller, Kiel

Berland, B., 1961. Nematodes from some Norwegian marine fishes. Sarsia 2: 1-50

Bishop, Y. M. M., Margolis, L. (1955). A statistical examination of Anisakis larvae (Nematoda) in herring (Clupea pallasi) of the British Columbia coast. J. Fish Res. Bd Can. 12: $571-592$

Grabda, J. (1978). Studies on parasitic infestation of blue whiting (Micromesistius sp.) Acta Ichthyol. Piscat. 8: 29-40

Jarling, C. (1982). On the helminth fauna of the smelt (Osmerus eperlanus L.) in the Elbe estuary. Arch. Hydrobiol. Suppl. 61: 377-395

Kahl, W. (1936). Über den Befall des Stints mit Larven des 

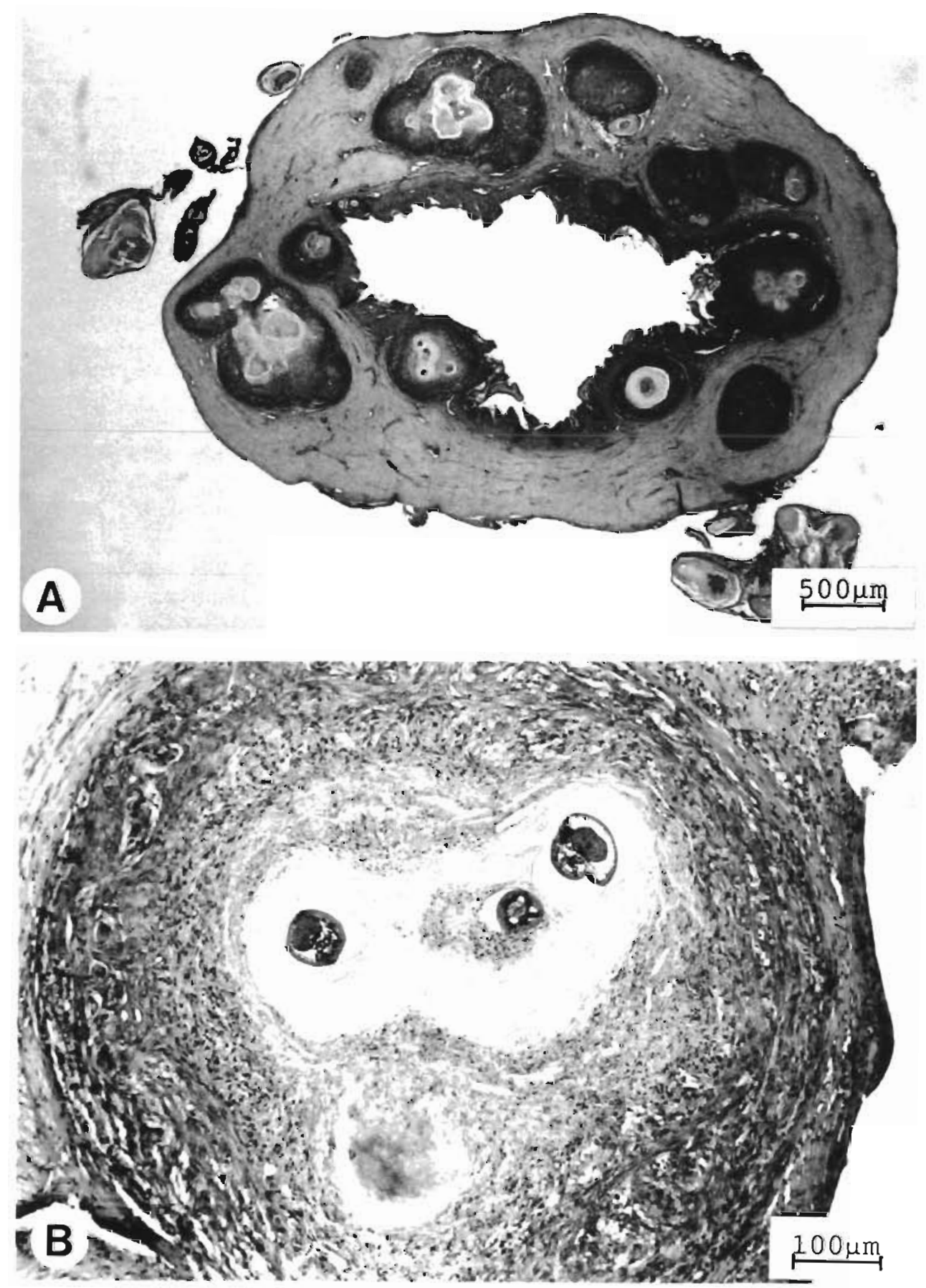

Fig. 8. Osmerus eperlanus. (A) Histological section through infected stomach wall of Osmerus eperlanus. (B) Cellular infiltration around encapsulated nematode larvae

Fadenwurms Porrocaecum decipiens. Fischmarkt 7 $177-181$

Kerstan, S. (1991). Der Befall von Wattenmeerfischen 1988-1990 mit Nematodenlarven. Ph. D. Thesis, University of Kiel

Lick, R. R. (1991). Untersuchungen zu Lebenszyklus (Krebse, Fische, marine Säuger) und Gefrierresistenz anisakider Nematoden in Nord- und Ostsee. Ph.D. thesis, University of Kiel

Lillelund, K. (1961). Untersuchungen über die Biologie und Populationsdynamik des Stintes Osmerus eperlanus (Linnaeus 1758), der Elbe. Arch. FischWiss. 12, Beiheft: 1-128
Margolis, L., Esch, G. W. Holmes, J. C., Kuris, A. M., Schad, G. A. (1982). The use of ecological terms in parasitology. (Report of an ad hoc committee of the American Society of Parasitologists.) J. Parasitol. 68: 131-133

Möller, H. (1984). Daten zur Biologie der Elbfische. Verlag Heino Möller, Kiel

Möller, H., Anders, K. (1986). Diseases and parasites of marine fishes. Verlag Heino Möller, Kiel

Moller, H., Klatt, S. (1990). Smelt as host of the sealworm (Pseudoterranova decipiens) in the Elbe estuary. Can. Bull. Fish. Aquat. Sci. 222: 129-138

Petter, A. J. (1969). Enquéte sur les nematodes des poissons de 
la région nantaise. Identification d'ascarides parasitant les sardines. Ann. Parasit. hum. comp. 44:559-580

Plötz, J. (1982b). Über den Lebenszyklus von Paracuaria tridentata und Cosmocephalus obvelatus (Nematoda, Acuariidae) von Seevögeln. Seevögel, Sonderband: 125-126

Smith, J. W., Wootten, R, (1975): Experimental studies on the migration of Anisakis sp. larvae (Nematoda: Ascaridida) into the flesh of herring, Clupea harengus L. Int. J. Parasit. 5: $133-136$

Voigt, H.-R. (1975). A checklist of the parasites on the smelt

Responsible Subject Editor: W. Körting, Hannover, Germany
(Osmerus eperlanus L.) Inf. Parasitol. Inst. Soc. Scient. Fennica 14: 28-48

Voigt, H.-R. (1981). A survey of the parasites from the Baltic smelt, Osmerus eperlanus L. Inf. Parasitol. Inst. Abo Akademi 16: 62-65

Voigt, H.-R. (1989). Parasiten beim Ostseestint, Osmerus eperlanus (Linnaeus, 1758). Ph.D. thesis, University of Helsinki

Wong, P. L., Anderson, R. C. (1982). The transmission and development of Cosmocephalus obvelatus (Nematoda: Acuarioidea) of gulls (Laridae). Can. J. Zool. 60: $1426-1440$

Manuscript first received: November 25, 1991

Revised version accepted: February 7, 1992 